\title{
The Iranian Constitution: A Compilation of Irreconcilable Articles
}

\author{
Sara Zalzar ${ }^{1,}$, , Sadegh Zibakalam ${ }^{2}$ \\ ${ }^{1}$ Department of Political Science, Azad University, Chaloos Campus, Chaloos, Iran \\ ${ }^{2}$ Department of Political Science, School of Law \& Political Science, Tehran University, Tehran, Iran
}

Email address:

sarazalzar@gmail.com (S. Zalzar), sadeghzibakalam85@gmail.com (S. Zibakalam)

${ }^{*}$ Corresponding author

\section{To cite this article:}

Sara Zalzar, Sadegh Zibakalam. The Iranian Constitution: A Compilation of Irreconcilable Articles. Journal of Political Science and International Relations. Vol. 2, No. 4, 2019, pp. 93-100. doi: 10.11648/j.jpsir.20190204.13

Received: September 11, 2019; Accepted: October 24, 2019; Published: December 17, 2019

\begin{abstract}
The current Iranian constitution is the product of two irreconcilable and at times contradictory perspectives, i.e., a merger of the traditional guidelines from Shiite Islam (or Sharia law) with some principles similar in spirit to the French constitution. The purpose of this literature review is to objectively examine the contents of the Iranian constitution and elaborate on the similarities and differences compared with the principles enshrined in the French constitution that made France a major cradle of Western democracy. Despite the limited analytical literature available on the subject, the authors selected the relevant articles and books to critically compare and contrast the language and spirit of the Iranian constitution versus its French counterpart. The Iranian constitution is a reflection of the Islamic theocracy and fundamentalism, combined with democratic-appearing but irreconcilable articles to govern the nation's affairs by three branches of independent yet controlled government. The constitution provides the freedom to obey the absolute and unaccountable Leader, and the 177 articles that are claimed to be sufficient for prosperity in this world and the eternal life after. The outcome of the Iranian constitution, which was never tested in a real society before its ideals were put into practice in Iran, suggest that the Islamic guidelines are not reconcilable for the most part with those of the modern democracies as a method of governance in the $21^{\text {st }}$ century.
\end{abstract}

Keywords: Constitution, Democracy vs Theocracy, Sharia Law, Globalization, Fundamentalism, Separation of Powers

\section{Introduction}

The current Iranian constitution, adopted since the Islamic revolution in 1979, is clearly and uniquely two documents with two perspectives. On the one hand, it has embraced the traditional Islamic teachings. On the other hand, it has included some sections that originate from Western modernity and democratic principles. Obviously, this is a rather awkward mixture of irreconcilable principles, even though it was termed "Islamic democracy" by the founding revolutionists. With respect to the awkward combination of the principles in the Iranian constitution, numerous discussions, controversies and sociological disputes have immerged in the literature to date $[1,2]$. The analysis of the findings reveal the various causes and factors that influenced the occurrence of Iranian Islamic revolution, the characteristics of its foundations and the resultant constitution that evolved from it.

The unique concept of "Islamic democracy" is apparently an attempt to seek and establish a new identity for the Iranian society with deeply rooted cultural diversity and religious beliefs. This rather costly legal, social and political movement is consistent with the identity-seeking trend emerging or being developed in a number of Muslimmajority nations. A comprehensive description of this trend has been elaborated in a book entitled "The Power of Identity" [1]. The author of this book believes that identityseeking and globalization are the two prominent yet contrasting trends evolving as new strong social movements in certain societies, which are awakening calls to the rest of the world [1]. The views of several political thinkers [3-5] support the fact that identity-seeking is linked in part to globalization, both of which related to the uprisings in the Islamic societies in recent years. 
The aims of this review article are to introduce major foundational aspects of the Islamic revolution and its constitution, such as: $a$ ) the logics for the combination approach to the constitution inspired by the French counterpart; $b$ ) the constitution's role in shaping and structuring governance; and, $c$ ) the system's accountability toward the nation's cultural identity while respecting democratic principles and societal demand for modernity. The approach of this article is consistent with those of Manuel Castells [1] and Roland Robertson [2], both of whom suggest that the current challenges facing the developing world, including Islamic countries, are in line with globalization, identity-seeking trends and cultural fundamentalism.

\section{Method}

We searched the Internet, using the following keywords: French and Iranian constitutions; paradox of democracy versus theocracy; Sharia law; globalization and the Middle East; Islamic fundamentalism; and separation of religion and state. We identified 86 sources, such as books, published commentaries, articles and reviews. Of these sources, 40 contained one or more of the selected keywords, and had been indexed by one or more of the reputable databases. The selected articles were reviewed by the first author, who is a political scientist. A second individual, who is a professor of law and political science, further reviewed the selected literature and approved the final 40 articles. The two reviewers deliberated on the relevance of the reviewed topics and tabulated their findings for mutual approval and inclusion in the final draft of the manuscript.

\section{Literature Review}

\subsection{The Original Concept}

The original concept of the Islamic Republic of Iran (IRI) stems from the merger of traditional and cultural values with those borrowed from the modern world. In an attempt to logically classify the world democracies, IRI should be considered having a unique concept of governance, with commonalities and differences with Western liberal democracies. Many nations in the Middle East, such as Iran, have attempted to develop unique models of democracy in the hope of being in agreement with their local and cultural traditions [6-9]. Sometimes, these nations either mildly critique or outright reject some of the Western democratic principles simply because they do not readily agree with or conform to their local traditions and diverse cultures. Further, these societies selectively adopt Western democratic principles, claiming that the local democracy may not be necessarily identical with those of the West $[8,9]$.

A major reason behind the pessimistic views of Islamic nations about Western democracies is their memory of the colonial era [10]. Many leaders in these countries believe that a superficial interpretation of democracy may arise from a colonial mindset [10]. They criticize the Western support for human rights violations in the developing world countries as being a pretext for regaining power over their affairs. On the other hand, Western politicians and human rights activists accuse most leaders in the Islamic nations of trying to set up their autocratic system, which stems from their hidden intention of governing their people autocratically [11]. These local and newly coined democracies face many challenges and have a long way to go before their versions of democracy eventually take deep roots [11].

Indeed, true democracy is not simply having elections or appointing politicians or social decision makers based on the people's vote [12]. A real democracy is having established, collective respect for the rule of law, protection of civil rights, a system of checks and balances to monitor decision makers, formulating an efficient government, and controlling the forces that have the potential to become autocratic, such as the military and security systems [13].

\subsection{Similarities Between the Iranian and French Constitutions}

Since the initial founders and theorists of the Islamic revolution favored the French constitution as a model, there are varying degrees of similarity between the two documents. As shown in Table 1, out of the 177 articles in the Iranian constitution, $44(24.8 \%)$ have varying similarities in language or concept with 25 articles from the French constitution.

Table 1. Similarities between the French and Iranian constitutions.

\begin{tabular}{lll}
\hline \multirow{2}{*}{ Fundamental Principle } & Iran (since 1989) & France \\
\cline { 2 - 3 } & Article Number (Section No.) & $3,4,66,68,77$ \\
\hline Civic Freedom & $3(7), 9,26^{*}, 27^{*}$ & $3,4,6$ \\
Election & $6,62-67,114,117$ & $1,2,26,66,68$ \\
Freedom of Expression & $3(7,14), 9,23,24^{*}, 25^{*}, 175^{*}$ & $2,3,5$ \\
Governance of Law & $2(5), 4^{*}, 56$ & $56-63$ \\
Guardian Council & $91-99$ & $3,4,6,7$ \\
Governance of People & $3(8), 6,58,59,117$ & $20,48,49$ \\
Leaders Accountability & $7,13,84,88,89,122$ & 20 \\
Leaders Responsibility & $84,122,137$ & 24 \\
Parliament & 7,52 & 3,24 \\
People Representation & 62 & 24 \\
Separation of Powers & 57 & $64,65,66$ \\
Supreme Court & 161,162 & 2,3 \\
Women's Rights & $3(14), 20^{*}, 21^{*}$ & 25 Articles \\
Total & 44 Articles & \\
\hline
\end{tabular}

\footnotetext{
${ }^{*}=$ Requires consistency between the article and the respective Islamic guidelines.
} 
Even though the French and Iranian constitutions share two of the fundamental articles regarding Guardian Council and Supreme Court with varying degrees of similarity in the language, there are major differences in the manner the two entities are appointed and the power they wield. Details of the two Iranian constitutional oversight bodies are described briefly below.

\subsubsection{Guardian Council}

Based on articles 91-99, the 12-member Iranian Guardian Council (six appointed by the Supreme Leader and six by the Parliament) has the following duties for six years:

a) Oversees all laws made by the Parliament for their consistency with the pertinent Islamic guidelines;

b) Interprets the articles of the Constitution; and,

c) Oversees general elections and referenda.

In addition, the Parliament loses its legitimacy in the absence of this Council. The members of the French Guardian Council; however, are appointed for nine years by the elected parliaments and President, based on the French articles 56-63.

\subsubsection{Supreme Court}

Based on articles 161 and 162, the Iranian Supreme Court oversees the consistent interpretation and enforcement of the laws in courts, based on the Islamic guidelines and the constitution, and is monitored by the Judiciary Head, who is appointed by the Supreme Leader. The 9-member French Supreme Court is appointed for life by the President, based on the French articles 64, 65 and 66.

\subsection{Differences Between the Iranian and French Constitutions}

Among others, there are four powerful regulatory bodies enshrined in the Iranian constitution that determine the course of the nation's political and social arena. These entities and many others are not found in the French constitution (see sections 3.3.1. to 3.3.10). As shown in Table 2 , the four regulatory bodies wield enormous power over the lives of Iranians in many ways. The most powerful entity is the office of the Supreme Leader, who has the final say in all affairs of the republic but is not accountable to anyone except for the Assembly of Experts whose members he appoints.

Table 2. Articles and oversight entities enshrined in the Iranian constitution, but not found in the French counterpart.

\begin{tabular}{|c|c|c|}
\hline Article & Entity & Composition \& Oversight Role \\
\hline $107-111$ & $\begin{array}{l}\text { Assembly of } \\
\text { Experts } \Omega\end{array}$ & $\begin{array}{l}\text { The 88-member body searches for and elects the Supreme Leader; sets his qualifications, duties, and term of office; oversees } \\
\text { his performance; and may dismiss him from the office. }\end{array}$ \\
\hline 112 & $\begin{array}{l}\text { Expediency } \\
\text { Council }\end{array}$ & $\begin{array}{l}\text { This 13-member council, appointed by the Supreme Leader, with legislative authority: to pass temporary laws (for a 3-year } \\
\text { period), to resolve conflicts between the Parliament and the Guardian Council, and to advise the Supreme Leader. }\end{array}$ \\
\hline 176 & $\begin{array}{l}\text { National } \\
\text { Security } \\
\text { Council }^{\Omega}\end{array}$ & $\begin{array}{l}\text { This } 13 \text {-member body sets the national security and defence policies; coordinates the political, social, cultural and } \\
\text { economical activities relevant to the national security and defence. All such initiatives are enforceable after approval by the } \\
\text { Supreme Leader. }\end{array}$ \\
\hline 110 & $\begin{array}{l}\text { Supreme } \\
\text { Leader }^{\Omega}\end{array}$ & $\begin{array}{l}\text { Has the final say in all affairs of the republic; sets general policies; declares referenda and/or war; commands the nation's } \\
\text { armed forces; appoints or fires oversight councils, Head of the Judiciary and other leaders; invokes the President; } \\
\text { coordinates the three branches of power; and issues amnesty orders. }\end{array}$ \\
\hline
\end{tabular}

$\Omega$ The oversight authorities, largely unelected, do not exist in the French constitution.

\subsubsection{Influence of Islamic Guidelines}

Unlike the French constitution, there is no separation of religion and state in the Iranian counterpart. To ensure the strict adherence with the Islamic Sharia law, derived from those of the Shiite religion, the Guardian Council has been given the ultimate authority over the interpretation and execution of all articles in the Iranian constitution and all laws made by the Parliament, or Majlis. Also, the Parliament cannot operate legitimately without the Council's approval. To make the point, the translated versions of the five articles from the Iranian constitution are shown below:

Article 4: All civil, judicial, economical, political, cultural, military, and administrative laws and regulations must be consistent with the Islamic guidelines. This requirement also applies to all of the constitutional articles and other government regulations and directives. The Guardian Council is the sole authority empowered to determine the required consistency between the constitutional articles and the Islamic guidelines.

Article 20: All individuals in the nation, whether men or women, are equal before the law, and are entitled to all human, political, economical, social and cultural rights, based on the Islamic guidelines.

Article 24: Print media are free to communicate all thoughts and ideas unless they are against the Islamic guidelines or people's rights. Details shall be determined by the pertinent laws.

Article 96: Determination of the consistency of all laws passed by the Parliament, with the Islamic guidelines is the ensured through the majority vote of the Guardian Council.

Article 170: Judges in all courts of law must deny implementing the government directives if they are inconsistent with the Islamic guidelines or are outside of the realm of the Executive branch of the government.

\subsubsection{New Illusionism}

The world realities today represent forgotten, old traditions and cultures, and the human search for self-identities. Routinely, we witness individual desires for returning to cultural origins and national definitions of self-identity. Social scientists believe that the Iranian people are affected by a condition termed "new illusionism", as evident by many 
old traditions becoming popular again [14-18]. The adoption of some of the old religious concept is evident by comparing the old Iranian constitution with the current one $[15,16]$. Illusionism is a condition which moves people away from realism and intellectual rationalism in dealing with personal and social affairs [18]. The proponents of "return to self" justify the concept as a side effect of the globalization phenomenon, which has opened up the horizons beyond imagination, making bewildered people return to their old and secure traditional, cultural and religious perspectives [3]. Even before the global explosion of information, some resistant forces were originated in community organizations, such as labor and professional associations, and political parties [1]. However, these forces have been attracted toward social causes and have shown vested interest in their traditional, religious and national values [19]. Religious fundamentalists, nationalists, women's right activists and environmentalists represent the identity pioneers that have taken advantage of the information era [1].

\subsubsection{Islamic Resurrection and Democracy}

Globalization accounts for a significant social change for humans living in the $21^{\text {st }}$ century [19], and it has also influenced the evolving Islamic concept of democracy in Muslim nations. In today's world, two major and concurrent social trends, although controversial, have evolved and are moving forward together. The first is a strong emphasis on spiritual or religious identity, and the second is democratization efforts that are initiated and evolving, particularly in Muslim nations. Esposito [4] and Wall [5], two social researchers, state that the democratization process and rebirth of Islamic concepts in many Muslim societies have complemented each other. Consequently, the strongest social dissent against many Islamic totalitarian states have stemmed from the people's demand for emphasis on Islamic traditions and heritage [20]. Improvement in people's basic education and dissemination of information worldwide have contributed significantly to people's demand for transparent governments and their rights to enjoy social and political reforms.

Further, democracy has its roots in the cultural and historical circumstances of various Islamic nations with their own characteristics and limitations. Obviously, democracy as defined and implemented in Europe and the United States may not be applied to Islamic nations. Honoring traditions is not necessarily bad in itself, depending on what the ultimate intentions and aspirations are. During the $19^{\text {th }}$ and $20^{\text {th }}$ centuries, political activists in Islamic countries frequently faced challenges under the dictatorial, totalitarian or colonial forms of their governments [21]. Under such circumstances, they often resorted to Islamic concepts as the means of materializing their true demand, which was establishing democracy as their ultimate goal [21].

\subsubsection{Islamic Fundamentalism}

During the 1950's and 1960's, social scientists believed that secularization was an inevitable part of modernization $[19,22]$. This concept was based on the assumption that political and economic developments promoted secular values while declining the role of religions in social and political life to insignificant levels. However, major developments occurred during the 1970's and 1980's that moved societies around the world in quite opposite directions than those previously predicted by social scientists. The power of religion, especially in the Middle East and also the "new right" in the U.S. and the "Reagan Revolution", rose to new heights [23]. These events perplexed social scientists who had difficulty understanding how the popular movements should be analyzed. We may admit that religious fundamentalism became a new approach in certain parts of the world, especially among deprived classes (Persian term "Mos-taz-afin"), to rise above the prevailing poverty and injustice and to enjoy acceptable standards of social welfare. Some Islamic fundamentalists; however, not only deny the contradiction between religion and modernization, but they insist that Islamic teachings are the key to ideal human lives, offering solutions to all social miseries worldwide [24].

\subsubsection{Dual Nature of Governance}

The founders of the Islamic Republic of Iran (IRI) tried to apply two distinct, although controversial; principles to build a unique model of governance that had not been tested in other societies before 1979. They claimed that it combined both the divine and human rules to ensure the prosperity of Iranians post revolution. Accordingly, the parliament was modified to abolish the Senate, and to deal with legislation and lawmaking. On the other hand, a Guardian Council was devised to make sure that the laws do not violate the Islamic guidelines, i.e., the "Sharia law", more specifically, Ja'fari jurisprudence. This model imposed two separate heads of the state, an elected President and an appointed Supreme Leader. The former represented the people's voice while the latter was the element of divine rule, overseeing all affairs of the IRI. This duality is well reflected in the articles of the Iranian constitution. Specifically, the $56^{\text {th }}$ article states: "the almighty God has the absolute power over everything and everyone, and that he has delegated part of his governing authority to humans."

Many social science experts believe that the duality of governance, specifically, the absolute divine power of the law over all affairs, prevents the establishment of a democratic society [25]. However, some insist that God has granted part of his authority to humans, therefore, they are allowed to establish a democratic system to run their own worldly affairs. A good example is the "Akhbari" versus "Osuli" school of Islamic jurisprudence that believes the divine power does not negate human governing authority; rather, it puts limits on such a system [26]. This implies that governance can be established by the people's will and they apply the divine will to their society, based on their common sense, which is a divine blessing. However, the divine power and its boundaries are open to differing interpretations. There remains one major question: What can ordinary people do in cases of contradiction in the interpretations of the divine will by high ranking members of the "Ulama" i.e., Ayatollahs? In 
such cases, some fundamentalists confidently argue that those who are highly educated in the Islamic Sharia law can issue the final judgment, i.e., "Fatwa" [27]. This and equally importantly the Ayatollah Khomeini's writings were the winning arguments for the inclusion of the Supreme Leader and Guardian Council in the Iranian constitution in 1979. Yet this is only one of the major differences between the Iranian constitution and the French counterpart, where the people's votes are the final determinant in all affairs of the French nation.

Expert lawyers and supreme justices believe that a third approach exists to writing national constitutions, and that is based on the law of the land. This approach is largely influenced by Plato's book, The Laws, the most revered work on political philosophy [28]. As asserted strongly by Ayatollah Khomeini, the father of Iranian revolution, Islamic laws are God's commandments and have the ultimate ruling power over all people and governing systems, including the prophet Mohammad and his disciples until the end of time [29].

\subsubsection{The Role of People vs the Supreme Leader}

In the French constitution, the role of people in determining the affairs and electing the leaders is well defined, primarily in articles 2 and 3 . Likewise, the politicians are accountable to people by law. The Iranian constitution honors both the role of people and the Supreme Leader in dealing with the social and political affairs of the nation [30]. Examples of Iranians' contributions to their social and political affairs include electing the President and representatives to the Parliament, the Assembly of Experts and the town or village councils. However, all authorities are subject to the veto power of the Supreme Leader and the Guardian and Expediency councils, both of which are appointed by the former. Even in the national elections, people have to elect from among those approved by the Guardian Council, which is under close watch of the Leader. As was discussed earlier, the elected authorities are only allowed to fulfill their duties in line with Islamic guidelines, which are open to differing interpretations even by Sharia experts [30]. The vetting mechanism is the Guardian Council, which is accountable to the Supreme Leader only. This oversight body also vets all affairs and proceedings of the parliament. The proponents of the office of Supreme Leader's absolute authority believe that ordinary people are not qualified enough, nor are they assumed to be aware of their interests or those of the government. They argue that their disqualification comes from the lack of both religious education and divine virtues. This concept is deeply rooted in the Sharia law of Shiite Islam and contradicts the Western merit principle.

\subsubsection{Islamic Versus Western Laws}

The European renaissance and the subsequent modernity era were neither accidental occurrences nor simple historical developments [31]. Rather, these events have deep seated roots in logical and analytical thinking promoted by Christian teachings, or those held by Roman and Greek philosophers
[31]. According to Max Weber, the German sociologist [32], the French and European modernity was evolved from the prevailing logical thinking and arguments employed to resolve social problems.

The original and theoretical social concepts that led to the French laws are largely different from those underpinning the Iranian laws. The French laws were primarily intended to promote social security, safety, justice and prosperity for people. However, the fundamentalists have repeatedly claimed that, under the Islamic revolution, Iranian laws not only provide for the prosperity of people in this world but also for the eternal life after death [30]. In this vein, the Catholic Church preaches that the privilege of enjoying prosperity in life, both worldly and eternal, is a concept plausible for those living within the church [33]. Therefore, the government is only responsible for providing the means for the prosperity of believers in this world [33].

\subsubsection{Separation Versus Centralization of Power}

To be relatively consistent with Western models of democracy, the three branches of power in Iran, i.e., executive, legislative and judicial, are apparently separate and expected to function independent of each other. However, as with the constitution, the inter-relationship of the three branches is affected by a combination of unique and poorly defined rules. The ultimate coordination among the three branches and their operating plans are dictated by the Supreme Leader, or by the Expediency or Guardian Councils, both of which are accountable to the Supreme Leader only [30]. Accordingly, the heads of the three branches are appointed or recommended by the Supreme Leader. After the monarchy era, the Iranian constitution, especially since its amendments in 1989, has rendered the three branches of power relatively interconnected and complex, even though the Executive and Legislative branches have functioned fairly independently. Conversely, under the French constitution, the executive branch must solely obey and execute the laws passed by the French parliament. This governance model was first proposed by the Swiss philosopher and political theorist, Jean-Jacque Rousseau (1712-1778), whose treatises have inspired Swiss lawmakers and the leaders of the French Revolution [34]. In the parliamentarian system, the three branches of government function independently of each other.

In the Iranian constitution and government, the three branches of power do not exist independently of each other's influence [30]. The Supreme Leader and the President are two different individuals, each with distinct responsibilities. The Supreme Leader is both the political and spiritual head of the nation, and this position oversees the affairs of the three branches of the government. The President is responsible for a large part, but not all, of the country's executive affairs [30]. Based on the original Article 113 (1979), the President was responsible for the coordination of the three branches of the government. However, his duties were diminished by the 1989 amendment and this authority was transferred to the Supreme Leader. There was a Prime 
Minister position in the original Iranian constitution post the Islamic revolution. However, it was abolished by the 1989 amendment. The President is now responsible for the appropriate implementation of the constitution under the auspices of various ministries. Also, he is sworn in by the Supreme Leader and is accountable to him and the parliament [30].

\subsubsection{Absolute Supreme Leadership}

In 1989, the word "absolute" (Persian equivalent: motlagheh) was heavily debated by the Council of Constitutional Amendment and was finally added to the Supreme Leader's title in Article 110 of the Iranian constitution, which describes his duties [30]. Such a position does not exist in the French constitution. Although the new authority for the Supreme Leader excited the Iranian fundamentalists, it disappointed the liberal minded members of the Council and the large majority of Iranians as well. The fundamentalists interpreted the word "absolute" as being in line with the supremacy of God and the rule of Shiite Sharia. The liberals viewed the word as a signal for potential dictatorship down the road. The new title suggested that the fundamentalists meant to establish an autocratic government rather than a people's republic. However, in the official declaration of the amendment, they claimed that the new authority did not grant the Supreme Leader the right to dictate his personal will or to promote such a government. However; most experts believe that "absolute power" in an individual is not consistent with a Republic, where the government is accountable to people only.

Currently, the balance of power as set by the Iranian constitution is not consistent with the ideals of Montesquieu (1689-1755), the French political thinker [35]. A paradox in the Iranian constitution is that the three branches of the government are seen as partners thriving to reach a common goal, but they are actually competing forces that need to be balanced by the Supreme Leader. The authors of the constitution did not consider that such a vast and absolute authority can persuade the Supreme Leader toward autocracy and dictatorship [30]. The proponents assert that the prerequisites for the position, i.e., justice and virtuosity, are sufficient to keep the Supreme Leader from becoming a dictator. Perhaps they had forgotten the Montesquieu's assertion that "power can only be balanced with power" [35].

\subsubsection{Freedom Versus Obedience}

Freedom, both in Islam and the Iranian constitution, is defined paradoxically [30]. Based on Islamic teachings, human submission to God leads to his freedom from the slavery for other humans and, therefore, grants him absolute freedom in life [36]. This concept asserts that nobody should obey another human unless it leads to obedience toward God [36]. Interestingly, the same teachings assert that nobody has the right to force others to obey another human or to deprive them of the freedom of thoughts, belief and legitimate actions [37]. The authors of the Iranian constitution should have devised a reliable mechanism to ensure that people's legitimate freedom was safeguarded and not subjected to absolute obedience, which has lead to the lack of or conditional freedom.

\subsection{Paradox of Democracy Versus Religion}

There are numerous models for the interpretation of democracy. These models may be based on the people's collective merits, professions, contributions, negotiations, agreements or the will of the majority [38]. Religious democracy is a new concept advocated during the late twentieth century, especially since the anti-monarchical revolution that took place in Iran in 1979. Considering democracy models, one may conclude that democracies are individual and singular interpretations of people, rather than being collective and plural agreements. Expert sociologists believe that there are many inconsistencies between the generally accepted models of democracy and that advocated by Islamists $[38,39]$. The inconsistencies are largely due to the differences between realism and the Islamic belief structure, revolving around oneness of faith and God, and submission to dictated commands in Islam [39].

Given the plurality of ideas, nobody can claim that the truth comes from one source only. Indeed, the truth is spread so widely that individual ideas contain both truth and error; therefore, no single opinion or idea is superior over others. Evidently, the plurality of ideas holds that people are free to choose the beliefs they may like, whether they are divine or not. Another model of social freedom, termed libertarianism, calls for absolute impartiality of the government on morality [40]. It is conceivable that this model may lead to anarchy. One may wonder if it would be possible to have a society in which no set individual values or behaviors would be superior. In this vein, the concept of Islamic democracy, as a model, may neither be easily rejected nor totally accepted.

\section{Conclusions}

The authors of the Iranian constitution must have realized the immense task of merging articles from both the French constitution and Islamic sources was not an easy task, if at all plausible. They were aware that the selected French articles had been tested in real life for centuries, unlike those adopted from the Sharia law. However, they insisted on impressing the world with a new constitution, with theoretical merits for the worldly and eternal lives of unsuspecting Iranians. The Iranian constitution is a compilation of the Islamic theocracy and fundamentalism, combined with democratic-appearing but irreconcilable articles to govern the nation's affairs by the three branches of government. The three branches are nominally independent yet controlled government. The constitution provides the freedom to obey the absolute and unaccountable Leader, and the 177 articles that are claimed to be sufficient for prosperity in this world and the eternal life after. The outcomes of the constitution are self explanatory as the Republic concludes its $40^{\text {th }}$ anniversary in February 2020. 


\section{Conflict of Interest}

There was no conflict of interest with any entity in conducting this review.

\section{Acknowledgements}

The authors appreciate the Department of Political Science, Azad University, Chaloos Campus, Chaloos, Iran, for their support of this thesis project. They are grateful to: Dr. Matthew Shannon, Associate Professor of History at Emory \& Henry College, Emory, Virginia, USA, for his excellent review of the final version of the manuscript. Also, we thank Dr. Kamran Tavakol and Dr. Simin Bakhshi of MERCI Editorial Consultants International, Marion, VA, USA, for their excellent translation of the original manuscript from Persian language and the careful review and editing of its drafts. This project was totally funded by the first author.

\section{References}

[1] Castells M. The Power of Identity (The Information Age). Blackwell Publishers. Oxford, UK, 2003.

[2] Robertson R. European Globalization in Global Context. Palgrave Macmillan. Hampshire, UK, 2014.

[3] Catarina Kinnvall C. Globalization and Religious Nationalism: Self, Identity, and the Search for Ontological Security. Political Psychology. 2004; 25 (5): 741-767.

[4] Esposito JL. Who speaks for Islam? What a billion Muslims really think. Gallup Press. New York, USA, 2009.

[5] Wall J. Democratizing Democracy: The Road from Women's to Children's Suffrage. International Journal of Human Rights. Special Issue, ed. Sonja Grover. 2014; 18 (6): 646-659.

[6] Chtatou M. Is Democracy out of Reach for Much of the Middle East? Available at: https://intpolicydigest.org/2017/01/24/democracy-reachmuch-middle-east/.

[7] Hamid S. The Struggle for Middle East Democracy. Brookings University. Available at: https://www.brookings.edu/articles/the-struggle-for-middleeast-democracy/.

[8] Yildirim N. Leadership in the Middle East: Culture, Power or Democracy? Turkey Tribune. Available at: https://www.turkeytribune.com/2017/05/leadership-in-themiddle-east-culture-power-or-democracy/.

[9] Perlini C. Democracy in the Middle East: External Strategies and Domestic Politics. IRIA Report No. Available at: http://www.ir-ia.com/reports/Democracy-in-the-MiddleEast.pdf.

[10] Miller D. Is Islam a religion of peace? The West's definition of 'peace' differs dramatically from Islam's. Available at: https://world.wng.org/2014/10/is_islam_a_religion_of_peace.

[11] Levinson S, Balkin JM. Democracy and dysfunction: An exchange. Indiana Law Review. 2015; 50: 281-285. https://mckinneylaw.iu.edu/ilr/pdf/vol50p281.pdf.
[12] Van Reybrouck D. Why elections are bad for democracy. Available at: https://www.theguardian.com/politics/2016/jun/29/whyelections-are-bad-for-democracy.

[13] Report by the Secretary General of the Council of Europe. State of democracy, human rights and the rule of law: Available at: https://edoc.coe.int/en/an-overview/6926-pdfstate-of-democracy-human-rights-and-the-rule-of-law.html.

[14] Mizruchi S. Introduction to Religion and Cultural Studies. New Jersey: Princeton University Press. 2001. Available at: https://www.amazon.com/Religion-Cultural-Studies-SusanMizruchi/dp/0691005036/.

[15] Borbor D. A Comparative Overview of the Iranian Constitutions of 1906-07 and 1979. In: Iran and the Caucasus. $\begin{array}{llll}\text { Publisher, } \quad \text { BRILL. 2006; } 10 & \text { (2): 263-286. }\end{array}$ https://www.jstor.org/stable/4030928.

[16] Amir Arjomand S. Governance in the Constitutions of Iran: A comparative perspective. Stony Brook Institute for Global Studies. ISMC's Dialogues Series 2015-6; pp: 1-10. Available at: https:/www.aku.edu/govprogramme/papers/Documents/Said $\% 20$ Arjomand Governance $\% 20$ in $\% 20$ the $\% 20$ Constitutions $\%$ 20of\% 20Iran_ENGLISH.pdf.

[17] Garrett W. Social Consequences of Religious Belief. New Ecumenical Research Association (Unification Theological Seminary). Paragon House Publishers. New York, 1989.

[18] Lyden J. Enduring Issues in Religion: Opposing Viewpoints. Green haven Press, Inc., 1995. Available at: https://www.gettextbooks.co.in/isbn/9781565102606.

[19] Shannon MK. The Window: Negotiating Modernization and Rights during the Kennedy Era. In: Losing Hearts and Minds: American-Iranian Relations and International Education During the Cold War. Cornell University Press, Ithaca, USA. 2017; Chapter 2, pp: 43-68.

[20] Curtis M. Is Islamic Ideology Totalitarian? Available at: https://www.gatestoneinstitute.org/3348/islamic-ideologytotalitarian.

[21] Bale J. Islamism and Totalitarianism. In: Totalitarian Movements and Political Religions. 2009; 10 (2): 73-96.

[22] Rivera JE, Castillo S. The Secularization of Discourse in Contemporary Latin American Neoconservatism. The Religious Studies Project. https://www.religiousstudiesproject.com/podcast/thesecularization-of-discourse-in-contemporary-latin-americanneoconservatism.

[23] Walker J. Religious Belief and Violence in the Middle East. Available at: https://www.nobeliefs.com/religiouswars.htm.

[24] Horowitz J, Sahgal N. Modernizers vs. Fundamentalists: How Religion, Politics and Economics Shape Attitudes in the Muslim World. 2011. APSA 2011 Annual Meeting Paper. Available at SSRN: https://ssrn.com/abstract=1899738.

[25] Cerar Miro. The Relationship between Law and Politics. Annual Survey of International \& Comparative Law. 2009; 15 (1): 1-23. Available at: http://digitalcommons.law.ggu.edu/annlsurvey/vol15/iss1/3. 
[26] Said A. Three observations on religion, politics, and the Muslim Brotherhood. Social Science Research Council. Brooklyn, NY, USA. April 1, 2014 https://tif.ssrc.org/2014/04/01/three-observations-on-religionpolitics-and-the-muslim-brotherhood/.

[27] Atassi N. Democracy and Sharia Law: Mutually exclusive or mutually misunderstood? Chicago Monitor, June 5, 2013. http://chicagomonitor.com/2013/06/democracy-and-sharialaw-mutually-exclusive-or-mutually-misunderstood/.

[28] Baima NR. Plato: The Laws. Internet Encyclopedia of Philosophy. Florida Atlantic University. Florida, USA. Available at: https://www.iep.utm.edu/pla-laws/.

[29] 1979 Iranian Revolution and Ayatollah Khomeini's Role in the Revolution. Bartleby Research. Available at: https://www.bartleby.com/essay/1979-Iranian-Revolution-andAyatollah-Khomeinis-Role-PKJ8X3PZTC.

[30] Constitution of the Islamic Republic of Iran. Available at: https://en.wikipedia.org/wiki/Constitution_of the_Islamic_Re public_of_Iran.

[31] Fyffe CA. A History of Modern Europe - Vol. 2. Available at: https://www.questia.com/library/94956976/a-history-ofmodern-europe.

[32] Mitzman A. Max Weber, German sociologist. Available at: https://www.britannica.com/biography/Max-Weber-Germansociologist.

[33] Prosperity Theology. Available https://en.wikipedia.org/wiki/Prosperity theology.

at:

[34] Qvortrup M. The Political Philosophy of Jean-Jacques Rousseau. The impossibility of reason. Manchester University
Press. Manchester, UK. Available at: http://library.umac.mo/ebooks/b28028284.pdf.

[35] Boothe BB. Montesquieu defined separation of powers in democratic government (throwing out tyranny). Politics. Boothe Global Perspectives. Available at: https://bootheglobalperspectives.com/article/1523915876WB G288450464/montesquieu-defined-separation-of-powers-indemocratic-government-throwing-out-tyranny.

[36] Ahmad M. Elucidation of Freedom, Slavery and Islamic teachings. Al Islam: Ahmadyya Muslim Community. Friday Sermon, Nov. 25th, 2011. Available at: https://www.alislam.org/friday-sermon/2011-11-25.html.

[37] Sajid A. Common Moral Grounds for the Common Good: An Islamic Perspective. Universal Peace Federation. Available at: https://uk.upf.org/leadership-conferences/494-common-moralgrounds-for-the-common-good-an-islamic-perspective.

[38] Mondal P. Speech on Democracy: Meaning, Types and Problems of Democracy. Available at: http://www.yourarticlelibrary.com/speech/speech-ondemocracy-meaning-types-and-problems-ofdemocracy/31367.

[39] Inozemtsev V. The Cultural Contradictions of Democracy. The American Interest. Available At: https://www.the-americaninterest.com/2012/02/01/the-cultural-contradictions-ofdemocracy/.

[40] Somin I. More on libertarian skepticism about democracy - A rejoinder to Will Wilkinson. Washington Post. Available at: https://www.washingtonpost.com/news/volokhconspiracy/wp/2017/11/17/more-on-libertarian-skepticismabout-democracy-a-rejoinder-to-will-wilkinson/. 